\title{
The Influence of Job Stress, Job Satisfaction and Work Environment On Organizational Commitment of Keluarga Sehat Clinic Wedoro Sidoarjo
}

\author{
Safitri Nur Diana*, Bayu Airlangga Putra, Mochammad Arif \\ Faculty of Economics and Business, Narotama University, Jl Arief Rachman Hakim 51, Sukolilo, Surabaya, Indonesia
}

\begin{abstract}
This study aims to determine the effect of work stress, job satisfaction and work environment on Keluarga Sehat Clinic Wedoro Sidoarjo. This type of research is quantitative, where researchers distribute questionnaires as a medium for data collection and then processed into interval data which is then processed using SPSS18. The population and sample of this study are 36 employees of Keluarga Sehat Clinic Wedoro Sidoarjo. Hypothesis test results partially work stress partially negative and significant effect on organizational commitment, job satisfaction partially has a positive and significant effect on organizational commitment, and work environment partially does not significantly influence organizational commitment. And the results of the simultaneous hypothesis test was calculated to be 11.570 and included to be greater than Ftable 2.92. This means that Ho is rejected and Hi is accepted. And the significant value is 0,000 less than 0.05 . So job stress, job satisfaction and work environment simultaneously have a significant effect on organizational commitment. While the determination test obtained by the coefficient R Square 0.5202 means that the relationship between job stress, job satisfaction and work environment on organizational commitment has an effect of $52.0 \%$, while the remaining $48.0 \%$ is explained by other variables not included in the modeling.
\end{abstract}

Keywords: Job Stress, Job Satisfaction, Work Environment, Organizational Commitment

\section{Introduction}

Human resources are the driving elements of an organization, so that the organization can achieve certain goals. For human resources organizations are very important subjects, because they are managers and regulators of the course of a job in an organization. In the current global era, business entities must be more competitive in order to be able to survive facing fierce competition, how the strongest of the strongest will be able to survive. Excellence and success of an organization will not be separated from the important role of workers in it, which they are the underlying reasons for the bad business.

By improving the quality of Human Resources, it is expected to be able to work more productively and professionally so as to improve the performance it is expected to be able to better meet the required work standards. For this reason, each business entity has an interest in assessing organizational commitment. Loyal human resources will provide many benefits for the company. However, some problems related to workers who are not satisfied, due to certain factors in the place where they work, and this is meant to underlie employees who are less effective in carrying out their duties in the company. It is important to do research related to the issue of organizational commitment, to see the level of loyalty, sense of belonging to the organization and service of the company in the company, in order to find ways to relate it to what might arise.

Clinics that provide care for patients, which create clinics in it that provide employees who devote themselves and receive customers or patients seriously for the success of the clinic in building a good image in the eyes of its

\footnotetext{
* Corresponding author.

E-mail address: dianasaftr98@gmail.com (Safitri Nur Diana)
} 
customers. Therefore, employee commitment to the clinic is very important and if necessary related to the human resources in the clinic provided immediately addressed, so as not to have a negative impact on the organization. Organizations or clinics need to provide satisfaction to the workforce, so that they are more loyal to work.

After conducting interviews with sources in the clinic, it was found that conflicts related to work stress, job satisfaction and work environment at the Wedoro Sidoarjo Healthy Family Clinic, which made the level of organizational commitment of employees low. Involved from several employees who resigned from the clinic within the specified time period and also the problems of employees who are expelled from work, to employees who are often resolved while working. Therefore, researchers conduct research related to organizational commitment with work stress free variables, job satisfaction, work environment.

And the authors found several GAPs. In the preliminary studies which encourage this research reference, they include: Based on research by Putu Agus Yoga Ariawan, Ayu Sriathi 2018, the results of the study concluded that work stress had a negative and significant effect on employee organizational commitment. This shows that the higher the work stress experienced by the employee, the lower the organizational commitment. $\mathrm{R}$ Square is 0.578 . This means that 57.8 percent of the organizational commitment of PBF employees. PT. Banyumas can be explained by variations in work stress variables, job satisfaction, while the remaining 42.2 percent is caused by other factors outside the model.

Based on Errica Herjany's research, Innocentius Bernarto 2018, the findings of this study are that the work environment, job satisfaction has a positive effect on organizational commitment. On the other hand, work stress has a negative effect on organizational commitment. The contribution of this research can provide input to school $\mathrm{X}$ management to maintain and manage the work environment, job satisfaction, and work stress in order to be better so that teachers can make a better contribution to their performance and decide to work in the same school for more periods long. time. R-Square (R2) to find out the extent to which independent constructs explain dependent constructs. The results of the measurement $\mathrm{R} 2$ are 0.584 or $58.4 \%$, meaning that variations in the value of the construct of organizational commitment are explained by variations in the value of the stress of work, work environment and job satisfaction by $58.4 \%$. The remaining $41.6 \%$ is explained by other constructs

Based on research Lukmanul Hakim, Agi Syarif Hidayat 2018, The results showed that, job stress does not significantly influence organizational commitment, job satisfaction has a significant effect on organizational commitment.

Based on research on the Durukan Köse, Tuncay Köse 2017, from the results of the analysis, there is no statistically significant effect of intrinsic satisfaction on organizational commitment. Only extrinsic satisfaction is determined to be negatively significant to the continuing commitment and the positive effect on normative commitment. In other words, an increase in the level of extrinsic satisfaction results in a decrease in continuing commitment and an increase in normative commitment.

\section{Literature Review and Hypothesis}

\subsection{Relationship Between Job Stress with Organizational Commitment}

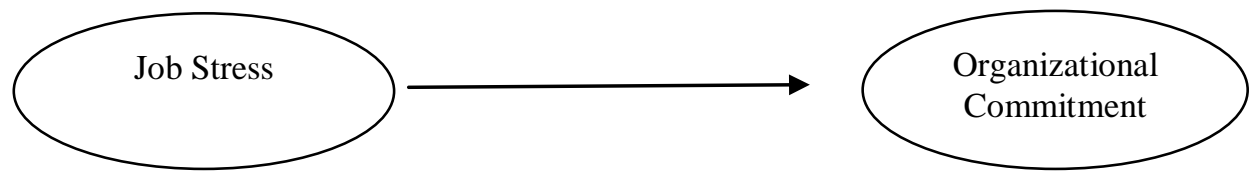

Job stress affects organizational commitment, one of the problems of stress such as demands for jobs that are not appropriate and tasks that do not fit the authority of the position can affect organizational commitment that causes organizational commitment to be low, the excessive effect of this stress is to increase employee intention to leave the organization and organizational performance is reduced (Cicei, 2012; Gayathiri \& Ramakrishnan, 2014). Khatibi et al. (2009) and Firth et al. (2004) states there is a negative relationship between work stress and organizational commitment, employees who have high stress levels have implications for the low commitment of their organizations. 
Likewise with Velnampy and Aravinthan (2013) which states that there is a negative relationship between work stress and organizational commitment.

H1: Work Stress partially has a significant negative effect on Organizational Commitment.

\subsection{Relationship Between Job Satisfaction with Organizational Commitment}

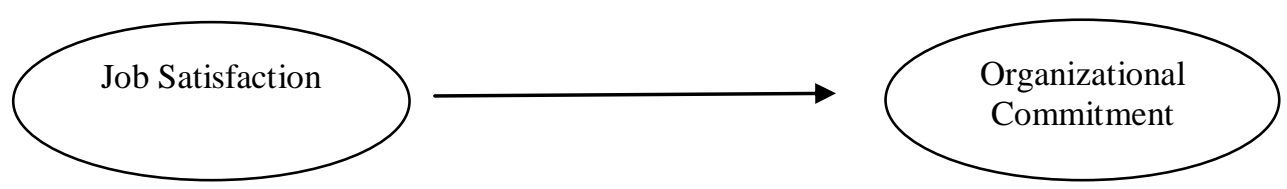

According to Robbins (2004) job satisfaction is a general attitude towards his job. Associated with a high level of job satisfaction has a positive attitude towards his job Like all opinions about job satisfaction consists of feelings, thoughts, and behavior of individuals who have relevance to their work (Jex \& Britt, 2008). Papinczak (2012) says that job satisfaction has an important role in increasing employee commitment to the organizations that support them. The results of the study (Errica Herjany \& Innocentius Bernarto 2018), found positive job satisfaction with organizational commitment.

H2: Job Satisfaction partially has a significant effect on Organizational Commitment.

\subsection{Relationship Between Work Environment with Organizational Commitment}

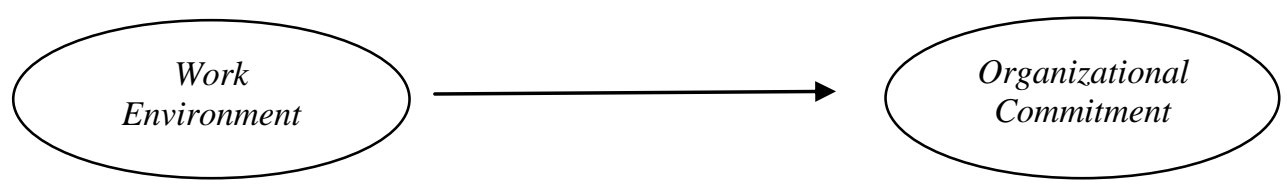

Mathis (2006: 99) explains that people who are relatively satisfied with their work will be more committed to the organization and people who are committed to the organization are more likely to get greater satisfaction. Job satisfaction is very important in an organizational environment because it has a relationship with employee behavior towards the organization and the environment. Job satisfaction can encourage organizational commitment. The results of the study (Errica Herjany \& Innocentius Bernarto 2018), found that the work environment had a positive effect on organizational commitment.

H3: Work Environment partially has a significant effect on Organizational Commitment

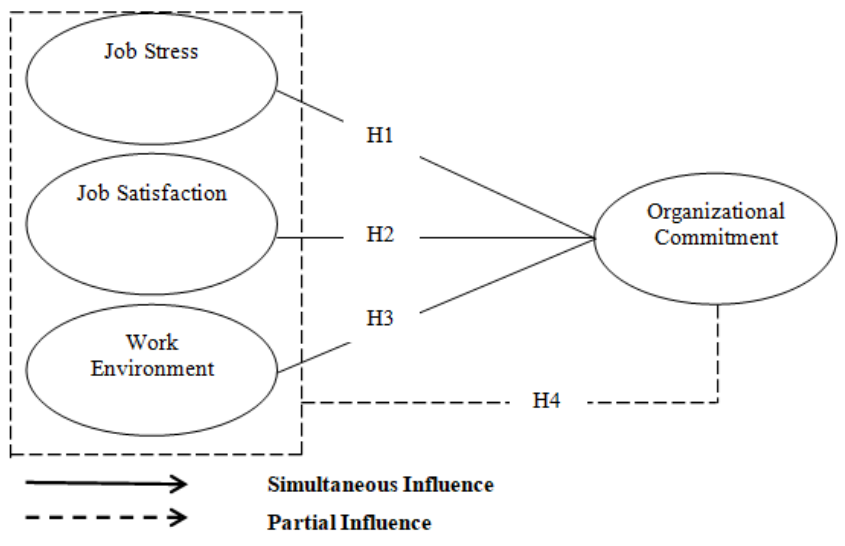

Fig. 1. Conceptual Model 


\subsection{Hypothesis}

H1 : Work Stress partially has a significant negative effect on Organizational Commitment.

H2 : Job Satisfaction partially has a significant effect on Organizational Commitment.

H3 : Work Environment partially has a significant effect on Organizational Commitment.

H4 : Work Stress, Job Satisfaction and Work Environment simultaneously have a significant effect on Organizational Commitment.

\section{Research Method}

This study aims to determine the effect of work stress, job satisfaction and work environment on organizational commitment of Keluarga Sehat Clinic Wedoro Sidoarjo. The independent variables in this study are job stress, job satisfaction and work environment. The dependent variable is organizational commitment. The target population is all medical employees and medical donors in Keluarga Sehat Clinic Wedoro Sidoarjo is 36 people. Furthermore, all members of the population are used as data sources or referred to by the census, because the population is small and easy to access.

The survey method was used to obtain data through the distribution of questionnaires to all medical employees and medical donors of Keluarga Sehat Clinic Wedoro Sidoarjo. Then, the data is processed using the SPSS version 18 application. Questionnaire items measure the role of work stress, job satisfaction and work environment of Keluarga Sehat Clinic Wedoro Sidoarjo employees on organizational commitment. All answers to work stress questionnaire items, job satisfaction and work environment were developed with a Likert scale using 5 points namely $1=$ disagree, $2=$ disagree, $3=$ neutral, $4=$ agree, and $5=$ strongly agree. Furthermore, each item is tested for validity and reliability. After that, the classic assumption test is done which is divided into 3 tests, namely multiclinearity test, heteroscedasticity test and normal test. Then the linear regression test, normal distribution test, $\mathrm{R}$ and Rsquare test are also processed using SPSS. And finally the hypothesis test is divided into two namely partial T test which is used to test each one independent variable on the dependent variable of work stress on organizational commitment, job satisfaction on organizational commitment, work environment on organizational commitment, and simultaneous $\mathrm{F}$ test that measures the overall effect The independent variable is the dependent variable on work stress, job satisfaction and work environment on organizational commitment.

\section{Result and Discussion}

4.1. Result

\subsubsection{Multiple Linear Regression Analysis}

Table 1. Results of Multiple Linear Regression Analysis

Coefficients $^{\mathbf{a}}$

\begin{tabular}{|c|c|c|c|c|c|c|c|c|}
\hline & \multirow[t]{2}{*}{ Model } & \multicolumn{2}{|c|}{$\begin{array}{l}\text { Unstandardized } \\
\text { Coefficients }\end{array}$} & \multirow{2}{*}{ 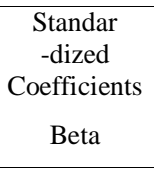 } & \multirow[t]{2}{*}{$\mathrm{t}$} & \multirow[t]{2}{*}{ Sig. } & \multicolumn{2}{|c|}{ Collinearity Statistics } \\
\hline & & $\mathrm{B}$ & $\begin{array}{l}\text { Std. } \\
\text { Error }\end{array}$ & & & & Tolerance & VIF \\
\hline \multirow{4}{*}{1} & (Constant) & 16.544 & 5.062 & & 3.269 & 0.003 & & \\
\hline & Job Stress (X1) & -0.287 & 0.099 & -0.359 & -2.889 & 0.007 & 0.973 & 1.028 \\
\hline & Job Satisfaction (X2) & 0.637 & 0.164 & 0.501 & 3.878 & $<0.001$ & 0.898 & 1.114 \\
\hline & Work Environment (X3) & 0.163 & 0.128 & 0.163 & 1.271 & 0.213 & 0.917 & 1.091 \\
\hline
\end{tabular}

Source: SPSS Output Data 
Based on the results of the calculation of the table, we get the linear regression equation:

$$
Y=16,544+(-0,287) X_{1}+0,637 X_{2}+0,163 X_{3}+e_{i}
$$

The interpretation of the regression model is as follows:

1. Work stress variable has a coefficient value of -0.287 which shows that if the Work Stress variable (X1) increases, it will result in a decrease in Organizational Commitment of -0.287 . The value is below zero, meaning negative value so that the higher the work stress, the organizational commitment will decrease.

2. The variable job satisfaction has a coefficient value of 0.637 which indicates that if the variable Job Satisfaction (X2) is increased, it will result in an increase in Organizational Commitment of 0.637. In addition, if job satisfaction is getting better, organizational commitment will also be higher.

3. The work environment variable has a coefficient value of 0.163 which indicates that if the Work Environment variable (X3) is increased, it will result in an increase in Organizational Commitment of 0.163. In addition, the better the work environment, the higher the organizational commitment.

\subsubsection{Determination Test $R$ and $R 2$}

Table 2. $\mathrm{R}$ and $\mathrm{R}^{2}$ Determination Test Results

\begin{tabular}{ccccccc}
\multicolumn{10}{c}{ Model Summary $^{\mathbf{b}}$} \\
Model & $\mathrm{R}$ & R Square & Adjusted R Square & Std. Error of the Estimate & Durbin-Watson \\
\hline dimension0 & 1 & $0.721^{\mathbf{a}}$ & 0.520 & 0.475 & 2.930 & 2.007 \\
\hline
\end{tabular}

a. Predictors: (Constant), Work Environment (X3), Job Stress (X1), Job Satisfaction (X2)

b. Dependent Variable: Organizational Commitment (Y)

Source: SPSS Output Data

Based on table 2 the results of data processing using the SPSS program obtained Adjusted value $(R 2)=0.475$, and $R$ Square coefficient of 0.5202 which means that the relationship between job stress, job satisfaction and work environment on organizational commitment has a low influence of 52\%. This means that organizational commitment at the Keluarga Sehat Clinic Sidoarjo Wedoro can be explained by work stress, job satisfaction and work environment by $52 \%$, while the remaining $48.0 \%$ is explained by other variables not included in the modeling. This shows that the independent variables only provide some of the information needed to predict the variation of the dependent variable.

\subsubsection{Normal Distribution Test}

Table 3. Normal Distribution Test Results

One-Sample Kolmogorov-Smirnov Test

\begin{tabular}{|c|c|c|c|c|c|c|}
\hline & & $\begin{array}{c}\text { Job Stress } \\
(\mathrm{X} 1)\end{array}$ & $\begin{array}{l}\text { Job Satisfaction } \\
\text { (X2) }\end{array}$ & $\begin{array}{c}\text { Work Environment } \\
\text { (X3) }\end{array}$ & $\begin{array}{l}\text { Organizational Commitment } \\
\text { (Y) }\end{array}$ & $\begin{array}{c}\text { Unstandardized } \\
\text { Residual }\end{array}$ \\
\hline \multicolumn{2}{|l|}{$\mathrm{N}$} & 36 & 36 & 36 & 36 & 36 \\
\hline \multirow[t]{2}{*}{ Normal Parameters ${ }^{\mathrm{a}, \mathrm{b}}$} & Mean & 24.08 & 18.25 & 29.56 & 26.08 & 0.002 \\
\hline & Std. Deviation & 5.062 & 3.184 & 4.032 & 4.045 & 2.802 \\
\hline \multirow{3}{*}{$\begin{array}{l}\text { Most Extreme } \\
\text { Differences }\end{array}$} & Absolute & 0.118 & 0.139 & 0.140 & 0.169 & 0.126 \\
\hline & Positive & 0.118 & 0.069 & 0.082 & 0.169 & 0.092 \\
\hline & Negative & -0.082 & -0.139 & -0.140 & -0.127 & -0.126 \\
\hline \multicolumn{2}{|c|}{ Kolmogorov-Smirnov Z } & 0.706 & 0.837 & 0.838 & 1.014 & 0.758 \\
\hline \multicolumn{2}{|l|}{ Asymp. Sig. (2-tailed) } & 0.701 & 0.485 & 0.484 & 0.256 & 0.613 \\
\hline
\end{tabular}

a. Test distribution is Normal.

b. Calculated from data.

Source: SPSS Output Data 
Based on Table 3, the shows Asymp. Sig. (2-tailed) processed per variable was found, work stress 0.701, job satisfaction 0.485 , work environment 0.484 , organizational commitment 0.256 , and processing results Unstandardized Residual 0.613, because of the Asymp value. Sig. (2-tailed) more than> 0.05 then the results are said to be all normal.

\subsubsection{Multicolininerity Test}

Table 4. Multicollinearity Test Results

Coefficients $^{\mathrm{a}}$

\begin{tabular}{lcccccccc}
\hline Model & \multicolumn{2}{c}{$\begin{array}{c}\text { Unstandardized } \\
\text { Coefficients }\end{array}$} & \multicolumn{2}{c}{$\begin{array}{c}\text { Standardized } \\
\text { Coefficients }\end{array}$} & & & \multicolumn{2}{c}{ Collinearity Statistics } \\
& B & $\begin{array}{c}\text { Std. } \\
\text { Error }\end{array}$ & Beta & t & Sig. & Tolerance & VIF \\
\hline & 16.544 & 5.062 & & 3.269 & 0.003 & & \\
Job Stress (X1) & -0.287 & 0.099 & -0.359 & -2.889 & 0.007 & 0.973 & 1.028 \\
Job Satisfaction (X2) & 0.637 & 0.164 & 0.501 & 3.878 & $<0.001$ & 0.898 & 1.114 \\
Work Environment (X3) & 0.163 & 0.128 & 0.163 & 1.271 & 0.213 & 0.917 & 1.091 \\
\hline a. Dependent Variable: Organizational Commitment (Y)
\end{tabular}

a. Dependent Variable: Organizational Commitment (Y)

Source: SPSS Output Data

Based on the table, it can be seen that the regression model does not have multicollinearity disorders. This can be seen from the tolerance value of work stress-free variables, job satisfaction and work environment that have a value greater than 0.1. And also the results of VIF show that all independent variables have a number smaller than 10 . Therefore, it can be concluded there is no multicollinearity between the independent variables in the regression model.

\subsubsection{Partial Test (T Test)}

Table 5. Results of Partial Test Calculations (T Test)

Coefficients $^{\mathrm{a}}$

\begin{tabular}{|c|c|c|c|c|c|}
\hline \multirow{2}{*}{ Model } & \multicolumn{2}{|c|}{ Unstandardized Coefficients } & \multirow{2}{*}{$\begin{array}{c}\text { Standardized } \\
\text { Coefficients } \\
\text { Beta }\end{array}$} & \multirow{2}{*}{$\mathrm{t}$} & \multirow{2}{*}{ Sig. } \\
\hline & $\mathrm{B}$ & Std. Error & & & \\
\hline (Constant) & 16.544 & 5.062 & & 3.269 & 0.003 \\
\hline Job Stress (X1) & -0.287 & 0.099 & -0.359 & -2.889 & 0.007 \\
\hline Job Satisfaction (X2) & 0.637 & 0.164 & 0.501 & 3.878 & $<0.001$ \\
\hline Work Environment (X3) & 0.163 & 0.128 & 0.163 & 1.271 & 0.213 \\
\hline a. Dependent Variable: Organiz & mmitmer & & & & \\
\hline
\end{tabular}

\section{1) Work Stress Variable (X1)}

Based on the table above, it is known that the variable of work stress on organizational commitment $\mathrm{t}$ value of -2.889 and a significance level of 0.007 is smaller than 0.05 . This means that the work stress variable (X1) partially has a negative and significant effect on organizational commitment (Y). And it implies that the higher the work stress, the lower the organizational commitment.

\section{2) Job Satisfaction Variable (X2)}

Based on the above table, it is known that the variable job satisfaction on organizational commitment tcount of 1.277 and a significance level of $<0.001$ is smaller than 0.05 . This means that the job satisfaction 
variable (X2) partially has a positive and significant effect on organizational commitment (Y). And implies the higher the job satisfaction, the higher the organizational commitment.

\section{3) Work Environment Variable (X3)}

Based on the above table, it is known that the work environment variable on the organizational commitment of $\mathrm{t}_{\text {count }}$ is 3.878 and the significance level of 0.213 is greater than 0.05 . This means that the work environment variable (X2) partially has no significant effect on organizational commitment (Y). And it implies that the work environment variable does not significantly influence organizational commitment.

\subsubsection{Simultaneous Test (F Test)}

Table 6. Simultaneous Test Calculation Results (F Test)

ANOVA $^{b}$

\begin{tabular}{clccccc}
\hline Model & & Sum of Squares & Df & Mean Square & F & Sig. \\
\hline \multirow{2}{*}{1} & Regression & 298.006 & 3 & 99.335 & 11.570 & $<0.001^{\mathrm{a}}$ \\
& Residual & 274.744 & 32 & 8.586 & & \\
& Total & 572.750 & 35 & & & \\
\hline
\end{tabular}

a. Predictors: (Constant), Work Environment (X3), Job Stress (X1), Job Satisfaction (X2)

b. Dependent Variable: Organizational Commitment (Y)

Source: SPSS Output Data

Calculated through the search formula $F_{\text {table }}$ found that the value of $F_{\text {table }}$ is 2.92 , and the value of $F_{\text {count }}$ is 11.570 so $\mathrm{F}_{\text {count }}$ is greater than $\mathrm{F}_{\text {table. }}$. And the significant value is 0,000 less than 0.05 . Therefore it can be concluded that work stress (X1), job satisfaction (X2), and work environment (X3) simultaneously have a significant effect on organizational commitment (Y).

\subsubsection{Heteroscedasticity Test}

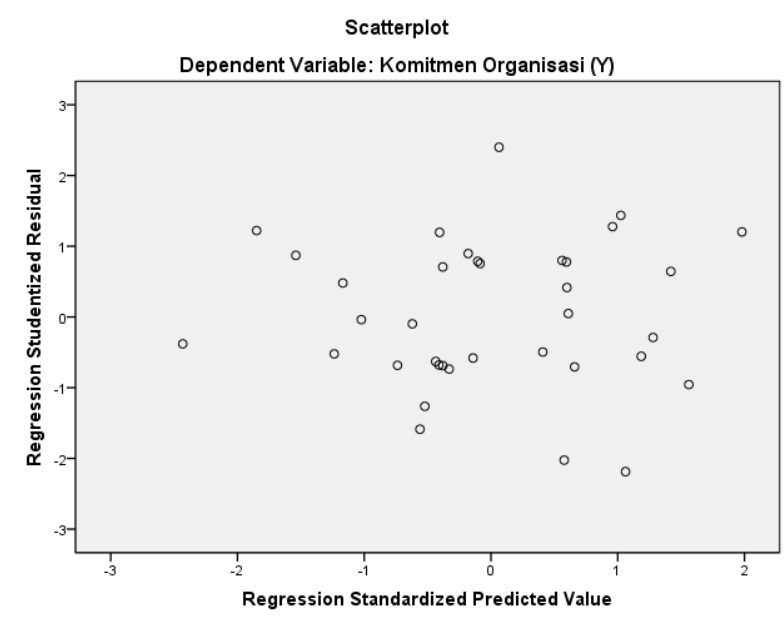

Fig. 2. Heteroscedasticity Test Results Source: SPSS Output Data

Based on the fig. 2, it can be seen that the dotted markings are irregular and do not form certain patterns, all data are scattered above and below the number 0 on the $\mathrm{Y}$ axis. Thus it can be concluded that in this model there is no heteroscedasticity problem. 


\subsection{Discussion}

Testing of this data involved 36 employees at the Keluarga Sehat Clinic Wedoro Sidoarjo, which consisted of 15 men and 21 women. There are 13 equal high school education, 2 graduates from D1, 12 from D3, 3 from D4, 5 from S1, 1 from S2. And the ages of 17-21 are 12 people (33.3\%), 22-26 are 10 people (27.8\%), ages 27-31 are 10 people (27.8\%), ages $32-36$ are 2 people (5.6\%), age $37>$ as many as 2 people $(5.6 \%)$.

The validity test results show that all data are valid because the Corrected Item-Total Correlation is greater than Rtable 0.3291, and the reliability test shows all realiable items because the results of Cronbach's Alpha are stated to be greater than 0.60. Asymp normal distribution test results were found. Sig. (2-tailed) more than 0.05. R and R2 determination test results obtained Adjusted value $(R 2)=0.475$, and R Square coefficient of 0.5202 which means that the relationship between work stress, job satisfaction and work environment on organizational commitment has a low influence of 52.0\%. This means that organizational commitment at the Keluarga Sehat Clinic Wedoro Sidoarjo can be explained by work stress, job satisfaction and work environment by $52.0 \%$, while the remaining $48.0 \%$ is explained by other variables not included in the modeling. The results of the multiple linear regression test on work stress found a coefficient value of -0.287 , so the conclusion was drawn that the higher the job stress the organizational commitment would decrease, job satisfaction found a coefficient value of 0.637 , and therefore the conclusion was drawn if the job satisfaction was getting better then the higher the organizational commitment, and for the work environment a coefficient value of 0.163 is found, therefore a conclusion is drawn that the better the work environment the higher the organizational commitment.

The results of the hypothesis test, partial test or T test were found in the work stress variable $t$-count of $-2,889$ and a significance level of 0.007 , which can be concluded that work stress (X1) partially has a negative and significant effect on organizational commitment $(\mathrm{Y})$, and contains meaning the higher the work stress, the lower the organizational commitment. In the $T$ test the job satisfaction variable tcount 1,271 and a significance level of 0,000 , which can be concluded that job satisfaction (X2) partially has a positive and significant effect on organizational commitment (Y), and implies the higher the job satisfaction, the organizational commitment the more high. Then in the $T$ test of work environment, the tcount value was 3.878 and the significance level was 0.213 , which means that the work environment variable (X2) partially had no significant effect on organizational commitment (Y), and implied that the work environment variable did not significantly influence organizational commitment. And the results of the simultaneous test or $\mathrm{F}$ test found that the value of $\mathrm{F}$ table is 2.92 , the value of Fcount is 11.570 so Fcount is greater than Ftable, and the significant value is 0,000. Then the conclusion is that work stress (X1), job satisfaction (X2), and work environment (X3) simultaneously have a significant effect on organizational commitment (Y).

The classic assumption test results, multicollinearity test found tolerance values of all independent variables are greater than 0.1, and VIF results show that all independent variables have numbers less than 10 , and it can be concluded that there is no multicollinearity between independent variables in the regression model. Furthermore, the heteroscedasticity test marks the points irregularly and does not form a specific pattern, all data are scattered above and below the number 0 on the $\mathrm{Y}$ axis, and it can be concluded that in this model there is no heteroscedasticity problem. Finally the normality test shows that all data are normally distributed, because all data are spread following a diagonal straight line, therefore it is assumed that the data is normal and follows the normality line.

\section{Conclusion}

Based on the results of the SPSS that the authors did adhere to the results of the questionnaire distributed to employees of the Keluarga Sehat Clinic Wedoro Sidoarjo, it was found that there was an influence between Work Stress Variables (X1), Job Satisfaction (X2) and Work Environment (X3) on Organizational Commitment (Y) in Keluarga Sehat Clinic Wedoro Sidoarjo. The following conclusions: 
1. Based on the T test (partial) between the variables of work stress on organizational commitment, it was found that the Tcount value of -2.889 was smaller than the table. And the significance level of 0.007 is smaller than 0.05 . This means that the work stress variable (X1) partially has a negative and significant effect on organizational commitment (Y). And it implies that the higher the work stress, the lower the organizational commitment. This shows the results of the first hypothesis analysis "Work Stress partially has a significant negative effect on Organizational Commitment" as evidenced.

2. Based on the $T$ test (partial) between the variables of job satisfaction to organizational commitment, the tcount value of 1.277 and a significance level of 0.000 is less than 0.05 . This means that the job satisfaction variable (X2) partially has a positive and significant effect on organizational commitment (Y). And implies the higher the job satisfaction, the higher the organizational commitment. It shows the results of the second hypothesis analysis "Job Satisfaction partially has a significant positive effect on Organizational Commitment" as evidenced.

3. Based on the T test (partial) between the work environment variables on organizational commitment, tcount was 3.878 and the significance level of 0.213 was greater than 0.05 . This means that the work environment variable (X2) partially has no significant effect on organizational commitment (Y). And it implies that the work environment variable does not significantly influence organizational commitment. This shows the results of the analysis of the third hypothesis "work environment partially significant effect on organizational commitment" is not proven true.

4. Based on the F test (simultaneous), the calculated Fcount is 11.570 and is greater than Ftable 2.92. This means that $\mathrm{Ho}$ is rejected and $\mathrm{Hi}$ is accepted. And the significant value is 0,000 less than 0.05 . Therefore the fourth hypothesis "Job Stress, Job Satisfaction and Work Environment simultaneously has a significant effect on Organizational Commitment" is proven true. Thus Work Stress (X1), Job Satisfaction (X2) and Work Environment (X2) simultaneously have a significant effect on Organizational Commitment (Y).

\section{References}

Ariawan, Putu A. Y. (2018). Pengaruh stres kerja dan kepuasan kerja terhadap komitmen organisasi karyawan PBF. PT. Banyumas Denpasar. 7(2), 964-992.

Herjany, E. (2018). Pengaruh Lingkungan Kerja , Kepuasan Kerja , dan Stres Kerja Terhadap Komitmen Organisasi Guru TK dan SD pada Sekolah X di Jakarta Barat. 18(2), 154-164.

Hakim, L. \& Hidayat A. G. (2016). The Effect of Job Stress and Job Satisfaction on Organizational Commitment. $110-119$

Köse, S. D., \& Köse, T. (2017). The Effect of Job Satisfaction on Organizational Commitment of Healthcare The Effect of Job Satisfaction on Organizational Commitment of Healthcare Personnel. (January). https://doi.org/10.9790/487X-1901025459 